\title{
Disain Turbin Model Nest-Lie Untuk Mikro Hidro
}

\author{
Lie Jasa ${ }^{1}$, I Putu Ardana ${ }^{2}$
}

\begin{abstract}
Water is one of the energy sources that has a large capacity and is spread throughout Indonesia. The main problem of hydropower is that the flow of water that flows is not continuous throughout the year. The characteristics of the location of each micro hydro placement are unique. A micro hydro that is placed in a particular location requires a turbine that matches the characteristics of the location. In this study a turbine was designed to obtain a new type of Nest-Lie turbine model that accommodates all existing location parameters. The method used is (1). Utilizing location data for initial designation, (2). find a mathematical model of turbine, (3). prototype models to be tested in the laboratory, (4). Make the actual turbine model for field trials. The results obtained from this study is that the RPM on the Nest-Lie turbine wheel produces a very significant difference, with the pressure at 28 Psi which is readable to produce RPM ranging from 157.2 -231.1 where the angle of position for 0o. 5o, 100, 15o. Highest RPM for 0o position angle and $22.5^{\circ}$ nozzle angle. and the nozzle angle that produces the highest RPM is at an angle of $22.5^{\circ}-25.5^{\circ}$ with an angle of $0^{\circ}-5^{\circ}$ position. The pressure generated on the nozzle channel is not a sum of each pressure, only an increase of $27 \%$. And RPM has increased by $20 \%$..
\end{abstract}

Intisari- Air merupakan salah satu sumber energi yang potesinnya besar dan tersebar di seluruh wilayah Indonesia. Masalah utama dari pembangkit tenaga air adalah debit air yang mengalir tidak kontinyu sepanjang tahun. Karakteristik lokasi masing-masing penempatan mikro hidro adalah unik. Sebuah mikro hidro yang ditempatkan pada lokasi tertentu diperlukan turbin yang sesuai dengan karakteristik lokasi yang ada. Dalam penelitian ini dirancang turbin untuk mendapatkan turbin model Nest-Lie jenis baru yang mengakomodir semua parameter lokasi yang ada. Metode yang dilakukan adalah (1). Memanfaatkan data lokasi untuk isiaiasi desain awal, (2). menemukan model matematis turbin, (3). membuat prototipe model untuk diuji di laboratorium, (4). Membuat model turbin yang sebenarnya untuk ujicoba lapangan. Hasil yang didapat dari penelitian ini adalah RPM pada roda turbin Nest-Lie menghasilkan perbedaan yang sangat signifikan, dengan tekanan pada 28 Psi yang terbaca pada menghasilkan RPM berkisar antara 157,2 -231,1 dimana sudut posisi untuk 0o. 5o, 10o, 150 . RPM tertinggi untuk sudut posisi 00 dan dengan pada sudut nozzle $22,5^{\circ}$. dan Sudut nozzle yang menghasilkan RPM tertinggi adalah pada sudut $22,5^{\circ}-25,5^{\circ}$ dengan sudut posisi $0^{\circ}-5^{\circ}$. Tekanan yang dihasilkan pada saluran nozzle bukan merupakan penjumlahan dari tekanan masing-masing, hanya terjadi peningkatan sebesar 27\%. Dan RPM mengalami peningkatan sebesar $20 \%$.

Kata Kunci-Mikro hidro, Turbin, Cross flow, Nest-lie.

\footnotetext{
${ }^{1,2}$ Dosen Teknik Elektro, Fakultas Teknik, Universitas Udayana, Jln. Jalan Kampus Bukit Jimbaran 80361 INDONESIA telp: 0361703315, fax: 0361-703315 e-mail: liejasa@unud.ac.id, antenakabeh@gmail.com
}

Lie Jasa: Disain Model Turbin Nest-Lie ...

\section{PENDAHULUAN}

Dunia saat ini mengalami krisis energi, karena energi yang berasal dari minyak bumi jumlahnya semakin terbatas. Kebutuhan energi terus meningkat sesuai dengan perkembangan jaman, sedangkan ketersediaan energi yang ada cendrung menurun. Untuk menutupi krisis energi ini, harus dicarikan pengganti dari sumber energi baru yang digunakan untuk mengatasi kelangkaan enegi, disamping itu tindangan penghematan harus terus digalakan untuk masyarakat luas. Sumber energi baru terbarukan sudah mulai didengungkan dan dipikirkan untuk dikembangkan secara besar-besaran oleh para peneliti dunia[1]Renewable energi yang banyak dikembangkan diantaranya bersumber dari Angin, Surya, Biogas, Air, Panas bumi dan Arus laut. Masingmasing sumber energi baru dan terbarukan memiliki keterbatasan bila dibandingkan dengan energi minyak. yang kita gunakan saat ini. Keterbatasan yang utama adalah kontinyuitas supplai dari energi yang dihasilkan. Sehingga masyarakat memandang energi terbarukan terkesan mahal, merepotkan, kapasitasnya kecil dan kurang praktis.

Indonesia memiliki lebih kurang 17.000 pulau dengan luas daratan $1.922 .570 \mathrm{~km}^{2}$ dan luas perairan $3.257 .483 \mathrm{~km}^{2}$. Wilayah Indonesia terletak di antara $6^{\circ} \mathrm{LU}-11^{\circ} \mathrm{LS}$ dan $95^{\circ}$ BT - $141^{\circ}$ BT: Daerah tropis terletak diantara $0^{\circ}-23,5^{\circ} \mathrm{LU}$ dan $0^{\circ}-23,5^{\circ} \mathrm{LS}$, daerah ini merupakan daerah peredaran matahari semu tahunan. Menjadikan Indonesia memiliki dua musim kemarau dan musim penghujan. Hal ini menjadikan air akan melimpah saat musim penghujan dan menyusut pada musim kemarau, karena lingkungan tidak terpelihara dengan baik. Air yang melimpah dapat dimanfaatkan untuk menghasilkan energi listrik yang murah, dan ramah lingkungan. namun akan terhenti saat musim kemarau karena tidak adanya air yang cukup untuk memutar turbin.

Hasil penelitian oleh British consulting rm and London economic untuk World Bank pada bulan Maret 2000, berkaitan dengan pengembangan mikro hidro terhadap 5 negara diantaranya Sri Langka, Peru, Nepal, Zimbawe dan Musambique [2], menunjukkan bahwa mikro hidro sudah dirasakan manfaatnya lebih dari 30 tahun, namun terkesan masih ketinggalan zaman dan cenderung ditinggalkan. Mikro hidro pada kondisi tertentu merupakan pilihan yang sangat menguntungkan bila dibandingkan dengan sumber pembangkit energi lain. Namun disisi lain tujuan untuk penyediaan tenaga listrik menjadi kendala secara finansial. Karena investasi terbesar sebuah mikro hidro adalah investasi awal saja sedangkan biaya pemeliharaan reatif rendah bila dibandingkan dengan sumber pembangkitan lain.

Program Diversikasi Energi (EDP) merupakan pemetaan sumber energi terbarukan atas permintaan energi di daerah pedesaan dan terpencil dengan mempromosikan energi terbarukan seperti; biomassa, surya, angin, arus laut dan hidro.

p-ISSN:1693 - 2951; e-ISSN: 2503-2372 
Sumber energi terbarukan memungkinkan sebuah daerah yang memiliki potensi alam akan berswasembada energi secara mandiri[3]. Memanfaatkan sumber energi terbarukan merupakan kunci utama membatasi adanya dampak perubahan iklim, karena kenyataannya sumber energi tersebut rentang terhadap perubahan iklim. Alasan ini yang membuat para investor kurang tertarik dalam bidang ini [4]. Jepang sebuah negara maju memiliki beberapa pasokan energi sendiri dan mengimpor sebagian besar energi untuk memenuhi kebutuhannya, tidak mengherankan setelah krisis minyak terjadi, penelitian mengenai energi terbarukan dikembangkan secara serius, disamping ikut berperan aktif menangani dampak perubahan iklim lingkungan global [5]

Mikro hidro juga memainkan peran penting dalam berkembang ekonomi dan sumber energi pedesaan di Cina [6]. Usaha lain yang dilakukan terhadap studi kasus delapan plant mikro hidro di daerah pedesaan di India, dengan memanfaatkan kanal irigasi, kaki Dam untuk memutar turbin yang disesuaikan dengan debit yang tersedia [7]. Sistem mikro hidro yang menggunakan sumber air dari air yang didaur ulang dari kegiatan rutin rumah tangga seperti mandi, juga mulai dikembangkan [8]Partisipasi Sektor Swasta pada proyek pengembangan mikro hidro di Rwanda [9], Pembangkit listrik tenaga mikro hidro dalam skala kecil dengan model "run-ofriver", tanpa bendungan dan merupakan salah satu pilihan teknologi yang paling hemat dan ramah lingkungan yang harus dipertimbangkan untuk listrik pedesaan di negara berkembang [10]. Semua ini menunjukkan bahwa mikro hidro merupakan hal yang sangat penting untuk terus dikembangkan akibat adanya keterbatasan energi dunia saat ini disamping dampak perubahan iklim global.

Namun keuntungan lain yang bisa disapatkan dari teknik operational pembangkit tenaga air [11] diantaranya (1). Relatif mudah distart dan distop tanpa daya dari luar (black start), (2). Bebannya mudah berubah-ubah, (3). Angka gangguan relatif rendah, (4). Pemeliharaan mudah .

Dalam penelitian diusulkan untuk menemukan sebuah karakterisitik mikro hidro yang ideal dalam sebuah pembangkit sekala kecil seperti yang dilakukan di dusun Gambuk, Pupuan Tabanan Bali [12][13], merupakan usaha nyata untuk mencari sumber energi baru. Mikro hidro yang dibuat menggunakan diameter turbin sebesar $200 \mathrm{~cm}$, lebar turbin $20 \mathrm{~cm}$, Head $17 \mathrm{~m}$, jumlah sudu 32, volume sudu 1.950 $\mathrm{cm} 3$, debit air 39 liter/s, menghasilkan daya listrik sebesar 700 watt. Berdasarkan analisis perhitungan, dengan debit air sebesar itu semestinya mampu menghasilkan listrik sebesar 2.000 watt. Namun energi listrik yang dihasilkan hanya $30 \%$ dari yang direncanakan. Nampak sekali efisiensi turbin rendah, rugi-rugri transmisi, rugi-rugi pipa pesat(penstock) menjadikan konversi energi air tidak bisa optimal. Masalah ini akan coba diselesaikan dan ditemukan jalan keluarnya sehingga masyarakat pedesaan merasa terbantu dan pemerataan pemanfaatan energi listrik bagi masyarakat luas menjadi semakin baik.

\section{STUDI LITERATUR}

Penelitian yang sudah dilakukan sebelumnya oleh para peneliti dunia untuk menunjang penelitian ini diantaranya mengenai model simulasi turbin mikro hidro berjudul Simulation model for optimizing energy allocation to hydro- electric and thermal plants in a mixed therma / hydro-electric power system Penelitian ini mengajukan sebuah model simulasi untuk ekonomi pengoperasian sistem listrik yang menggabungkan beberapa mikro hidro plan. Sebuah pengiriman optimal, berdasarkan metode Lagrange ganda, digunakan untuk satu jam dengan pemuatan unit termal. Biaya operasi dari sistem / termal pembangkit listrik tenaga air dievaluasi selama satu minggu periode yang mewakili berbagai musim tahun. Hasilnya digunakan untuk menentukan parameter desain yang optimal yang baru[14].

Penelitian lain mengenai rugi-rugi yang terjadi pada turbin mikro hidro adalah Minimum loss predispatch model for hydroelectric power systems. Penelitian ini mengajukan sebuah model predispatch yang meminimalkan kerugian transmisi yang dihasilkan pada sistem pembangkit listrik tenaga air yang terletak di Brasil. Kehilangan daya di pembangkit listrik tenaga air dikaitkan dengan penurunan efisiensi turbin-generator dan ketinggian air yang efektif. Kehilangan daya pada transmisi dihitung sebagai fungsi kuadrat aliran daya aktif[15].

Model mikro hidro yang dikembangkan di Malaysia diantaranya adalah Basic Rancangan Aspects of Micro hydro Power Plant and Its Potential Development in Malaysia. Penelitian ini menuliskan mengenai Pemasangan kincir air pertama kali di Sungai Fox di Wisconsin pada tahun 1882 menggunakan penggerak air untuk menghasilkan energi listrik. Mikro hidro adalah pembangkit listrik yang handal dan efisien sebagai sumber energi terbarukan dan bersih, dibandingkan dengan energi yang bersumber dari bahan bakar fosil. Mikro hidro tidak membutuhkan bendungan dan tanah yang luas untuk menyimpan air agar pasokan konstan. [16].

Penelitian mengenai model control mikro hidro berjudul Modeling and Control Rancangan for Governing Hydroelectric Turbines With Leaky Wicket Gates, Penelitian ini membahas mengenai masalah kontrol governor pada turbin pembangkit listrik tenaga air yang mengalami kebocoran. Pemodelan sistem dan kondisi perilaku turbin masing-masing digunakan untuk menentukan cara mengontrol kecepatan yang terbaik[17]. Dan model control Nonlinear Digital Simulation Model of Hydroelectric Power Unit With Kaplan Turbine. Penelitian ini membuat model Matematika dan simulasi unit daya dinamis menggunakan komputer. Penelitian ini menggambarkan PLTA unit dengan dua turbin Kaplan yang dapat diatur. Sudut pisau Runner dari turbin tersebut bervariasi tergantung pada kondisi operasi. Hal ini dengan tujuan untuk memastikan efisiensi maksimum dari turbin dalam semua operasi. [18]

Penelitian mengenai karakteristik dari turbin mikro hidro terlihat pada penelitian Fundamental Characterstics of Test Facility for Micro Hydroelecftric Power Generation System . Penelitian ini membahas mengenai fasilitas tes untuk sistem Mikro hidro dalam sekala laboratorium dalam bentuk pemodelan aliran air dialirkan melalui pompa dengan tujuan untuk menambah tekanan air saat jatuh[19]. Development of a real time simulator to test load and speed control systems of hydroelectric power plants Penelitian ini membahas mengenai simulator real-time dari pembangkit listrik tenaga air yang dikembangkan. Tujuannya adalah untuk menguji kecepatan dari sistem kontrol beban yang menggunakan hardware dan teknik pengulangan. [20]. 
Sedangkan hasil penelitian dalam sekala kecil dijumpai pada penelitian berjudul Small Hydro Power Plant Analysis and Development. Penelitian ini membahas mengenai keunggulan Mikro Hidro Power (MHP) dibandingkan PLTA skala besar. Mikro hidro power diidentifikasi sebagai alternatif yang baik untuk menghasilkan listrik konvensional bagi negara-negara berkembang di seluruh dunia. Mikro hidro power tipe run-of-river menghasilkan keuntungan ekonomi yang cukup besar. Namun masih dipengaruhi oleh berbagai tantangan teknis dan ekonomi [21].

Sedangkan penelitian aplikasi yang berkaitan dengan mikro hidro sekala kecil berjudul Maximum Power point tracking Applied on small Hydroelectric Power Plants Penelitian ini menyajikan skema baru untuk pembangkit listrik mikro hidro menggunakan grid kecil. Konfigurasi yang digunakan adalah mesin induksi sangkar bajing takserempak sebagai generator. Selain biaya pemelihataan mesin sangkar bajing asynchronous yang lebih rendah. penelitian ini juga menyajikan kontrol didasarkan pada pengaturan konverter back-to-back. Kontrol ini membuat kecepatan rotor disesuaikan dengan aliran air melalui turbin secara online [22].

Penelitian, yang dilakukan adalah untuk menemukan parameter turbin yang paling tepat untuk menghasilkan sebuah turbin dengan efisiensi tinggi untuk. Parameter yang digunakan untuk menentukan parameter diantaranya : debit air, head air, jari-jari turbin, tebal turbin, jumlah sudu, volume sudu sudut sudu, sudut nozzle dan posisi nozzle [23]. Karena potensi dari masing-masing lokasi yang ada berbeda-beda, maka dengan data kondisi yang ada dilakukan proses pelacakan untuk mendapatkan sebuah model turbin dengan efisiensi turbin yang paling maksimum. Nampak penelitian secara keseluruhan digbambarkan pada gambar 5. Terlihat mulai tahun 2015 sampai dengan tahun 2019, namun dalam perjalanan masih banyak yang dilakukan penyempurnaan dari penelitian yang sudah dilakukan sebelumnya. Hal ini sematamata untuk mendapatkan hasil akhir yang lebih baik dan sebagai pertanggung jawaban peneliti dalam pentas akademik dunia, yang menjadikan sebagai pijakan penelitian selanjutnya, dalam formum internasional.

\section{METODE}

Metodologi dalam penelitian ini disusun secara urut dan terstruktur dari beberapa tahapan proses penelitian yang dilakukan. Pada bagian ini, diuraikan prosedur untuk menyelesaikan penelitian ini yang dibagi dalam beberapa langkah seperti diperlihatkan pada gambar 11. Tahapan penelitian dimulai dengan (1). studi literature turbin air, (2). melakukan survei lokasi, (3). melakukan analisis data, (4). melakukan desain model, (5). melakukan simulas model, (6). Pembuatan model, (7). Instalasi model, (8). Melakukan Testing dan Pengukuran, (9).Melakukan penyempurnaan model. Urutan langkah diperlihatkan pada gambar 5.

Dalam usulan penelitian ini langkah-langkah detail yang akan dilakukan adalah sebagai berikut :

1. Mengadakan Survey lapangan di Dusun Gambuk Pupuan Tabanan dan Dusun Pagi, Kecamatan Penebel, Kabupaten Tabanan Bali untuk mendapatkan data-data dari lokasi saluran irigasi yang potensial untuk Lie Jasa: Disain Model Turbin Nest-Lie ... dimanfaatkan. Data berupa situasi lingkungan, dukungan masyarakat setempat, debit air, head, foto-foto potensi, yang nantinya dapat digunakan sebagai data dasar.

2. Analisis data yang ada dengan menghitung seberapa besar potensi air yang bisa dialokasikan untuk memutar turbin. Untuk menemukan parameter dan potensi yang dimungkinkan secara perhitungan diatas kertas, sehingga acuan awal berapa besar potensi yang mungkin dihasilkan dari lokasi tsb.

3. Melakukan desain berdasarkan hasil analisis data pada point 2. Untuk menemukan parameter dan potensi yang dimungkinkan secara perhitungan diatas kertas, sehingga acuan awal berapa besar potensi yang mungkin dihasilkan dari lokasi tsb.

4. Membuat simulasi model dari hasil analisis langkah 3 untuk menentukan kapasitas air maksimal yang bisa digunakan untuk memutar turbin, dengan tujuan menentukan kapasitas generator yang layak dipasang. Dengan maksud untuk mendapatkan model yang paling mendekati dengan kondisi dari lingkungan yang direncanakan. Seperti dimensi, diameter turbin, kapasitas generator dan kelengkapan lainnya.

5. Membuat prototipe model sesuai dengan simulasi model di workshop / bengkel. Disini desain yang sudah ditemukan, dibuatkan model nyata mikro hidro yang akan dibawa kelapangan.

6. Melakukan testing dilaboratoriu untuk menentukan mikro hidro berfungsi dan baik dan siap dibawa kelapangan untuk tahap ujicoba. Model yang sudah berhasil dibuat harus dilakukan uji testing mengenai kondisi perlatalan pendukung yang dapat berfungsi dengan baik. Untuk mengurangi kegagalan dilapangan karena keterbatasan kondisi dari mikro hidro yang dibuat.

7. Melakukan penyempurnaan dari model sesuai dengan hasil ujicoba langkah. Untuk mendapatkan hasil yang lebih baik dari yang sudah didapatkan.

8. Melakukan analisis data hasil pengukuran ujicoba setelah dilakukan penyempurnaan model

Langkah-langkah detail tahapan penelitian disertasi secara keseluruhan dapat dilihat pada gambar 6. Usulan kegiatan penelitian ini khusus akan dikerjakan pada tahun 2015-2019. Dimulai dengan tahapan analisa model dengan simulasi, selanjutnya tahapan analisa model plan dan mengukur rpm dari protipe model yang dibangun. Tahapan selanjutnya dilakukan analisis secara mendetail dari data-data yang didapatkan dengan beberapa metode, sehingga hasil keluarannya berupa model turbin dengan efisiensi tinggi.

\section{HASIL DAN PEMBAHASAN}

\section{A. Desain Sudu turbin Nest-Lie}

Sudu turbin dibuat dari bahan acrilik pada gambar 1, dirancang dengan sudu berbentuk segitiga, dengan jumlah sebanyak 16 buang, dan diameter turbin sebesar $50 \mathrm{~cm}$. Nestlie dibuat dalam bentuk lingkaran yang berada pada sisi leingkaran dalam yang ada pada dasar dari posisi sudu. Dengan tujuan air yang masuk melalui sudu, nantinya ada yang masuk kedalam Nest-Lie, sehingga air menjadi terjebak

p-ISSN:1693 - 2951; e-ISSN: 2503-2372 
didalam lingkarang Nest-Lie. Sehingga sejumlah volume air yang terjebak, akan menjadi torsi akibat turbin yang berputar secara terus menerus.
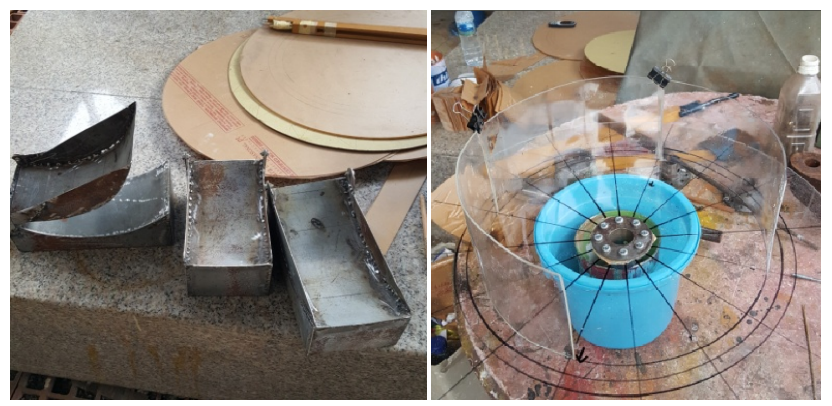

Gambar 1. Disain sudu turbin Nest-Lie dengan bahan acrilic

Selanjutnya untuk pengukuran RPM dari tubin Nest-Lie, yang diukur mengunakan parameter yang bisa diatur diantaranya ; Tekanan air dari pompa dari $20-28$ psi, sudut nozzle dari $0^{\circ}-36^{\circ}$. Semua data diambil secara berulang-ulang untuk setiap kondisi sebanyak 10 kali, hasil akhirnya dirataratakan untuk mengurangi kesalahan akibat pengukuran. Parameter pengukuran seperti pada gambar 2 .
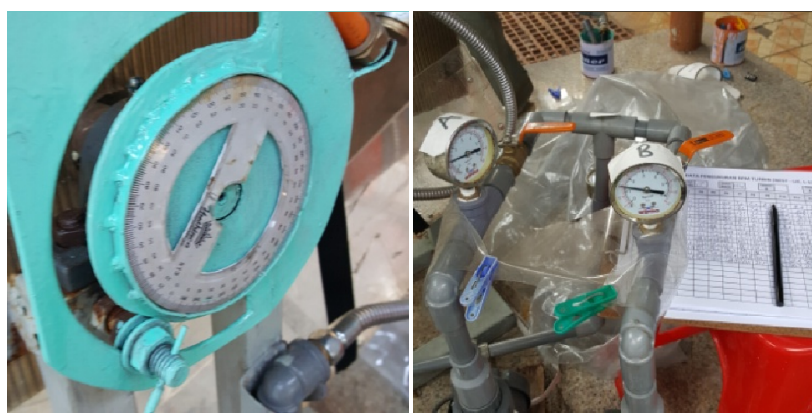

Gambar 2. Parameter pengukuran PRM turbin Nest-Lie

\section{B. Pengukuran RPM turbin Nest-Lie}

Selanjutnya hasil yang didapatkan dari pengukuran model prototype yang dibuat ditunjukkan dalam gambar 3,4,5 dan 6

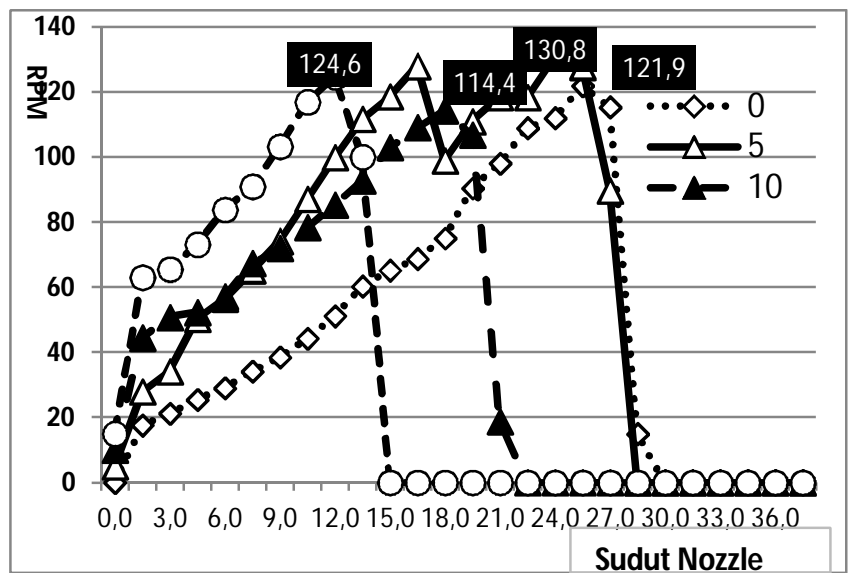

Gambar 3. Perbandingan sudut posisi terhadap sudut nozzle dengan kondisi pompa A hidup dan B pompa Hidup mati.
Perbandingan sudut sumbu $0^{\circ}, 5^{\circ}, 10^{\circ}$ dan $15^{\circ}$ dilakukan untuk melihat posisi jatuhnya air dari nozzle pada setiap posisi dari sudu turbin Nest-Lie. Percobaan dilakukan dengan menggunakan dua buah yaitu pompa A dan Pompa B. Komposisi percobaan terhadap pompa adalah : (1). Pompa A hidup, Pompa B mati, (2). Pompa A mati, Pompa B hidup dan (3). Pompa A dan B hidup. Yang berpengaruh terhadap komposisi ini adalah tekanan yang terbaca pada hydrometer pada pipa air menuju nozzle.

Hasil percobaan menunjukkan hasil pengukuran RPM pada roda turbin Nest-Lie tidak menghasilkan perbedaan yang signifikan, dengan tekanan pada 28 Psi yang terbaca pada menghasilkan RPM berkisar antara 114,4 -130.8 dimana sudut posisi untuk $0^{\circ} .5^{\circ}, 10^{\circ}, 15^{\circ}$. RPM tertinggi untuk sudut posisi 5 o dengan pada sudut nozzle $24^{\circ}$.

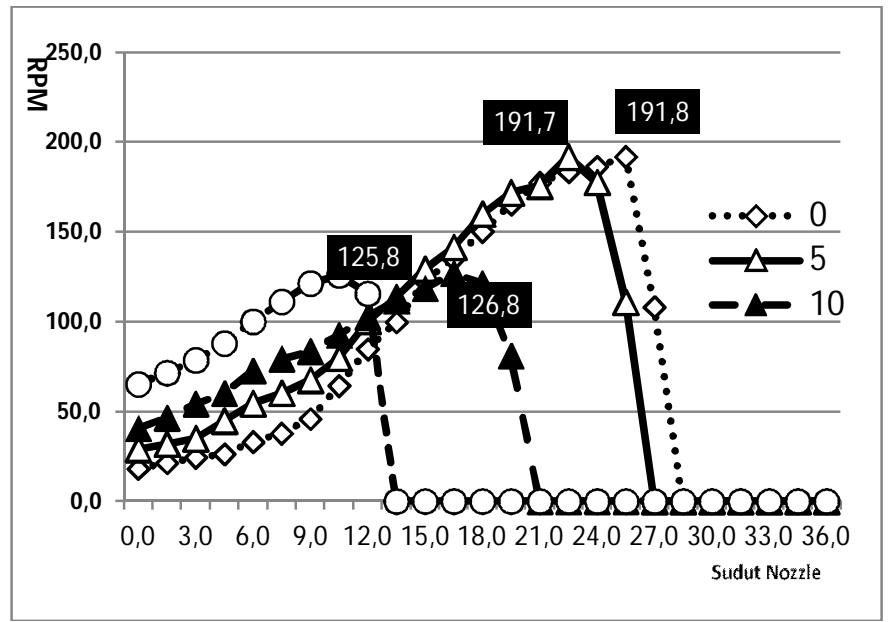

Gambar 4. Perbandingan sudut posisi terhadap sudut nozzle dengan kondisi pompa A Mati dan Pompa B Hidup.

Hasil percobaan menunjukkan hasil pengukuran RPM pada roda turbin Nest-Lie menghasilkan perbedaan yang signifikan, dengan tekanan pada 28 Psi yang terbaca pada menghasilkan RPM berkisar antara 125,8 -191.8 dimana sudut posisi untuk $0^{\circ} .5^{\circ}, 10^{\circ}, 15^{\circ}$. RPM tertinggi untuk sudut posisi 0o dan dengan pada sudut nozzle $25,5^{\circ}$.

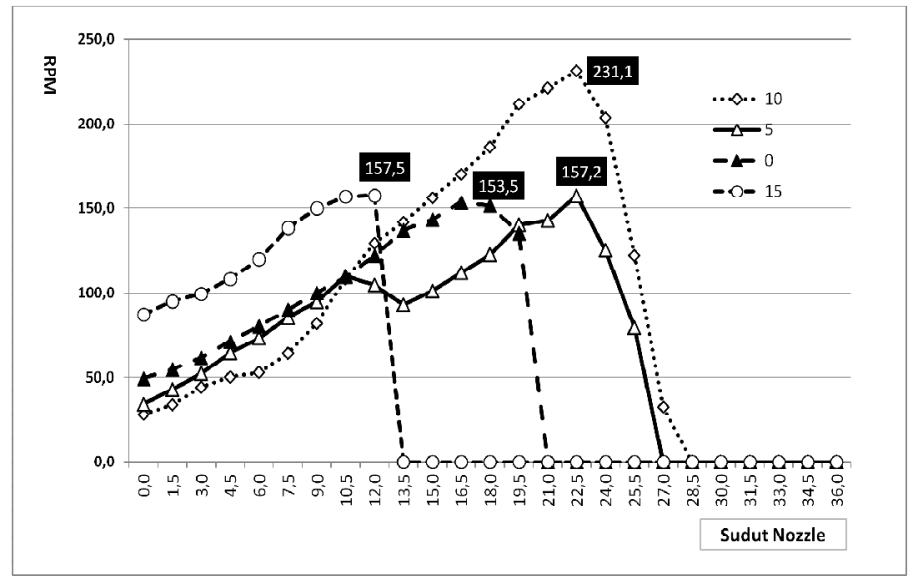

Gambar 5. Perbandingan sudut posisi terhadap sudut nozzle dengan kondisi pompa A dan Pompa B hidup. 
Hasil percobaan menunjukkan hasil pengukuran RPM pada roda turbin Nest-Lie menghasilkan perbedaan yang sangat signifikan, dengan tekanan pada 28 Psi yang terbaca pada menghasilkan RPM berkisar antara 157,2 -231,1 dimana sudut posisi untuk $0^{\circ} .5^{\circ}, 10^{\circ}, 15^{\circ}$. RPM tertinggi untuk sudut posisi $0^{\circ}$ dan dengan pada sudut nozzle $22,5^{\circ}$.

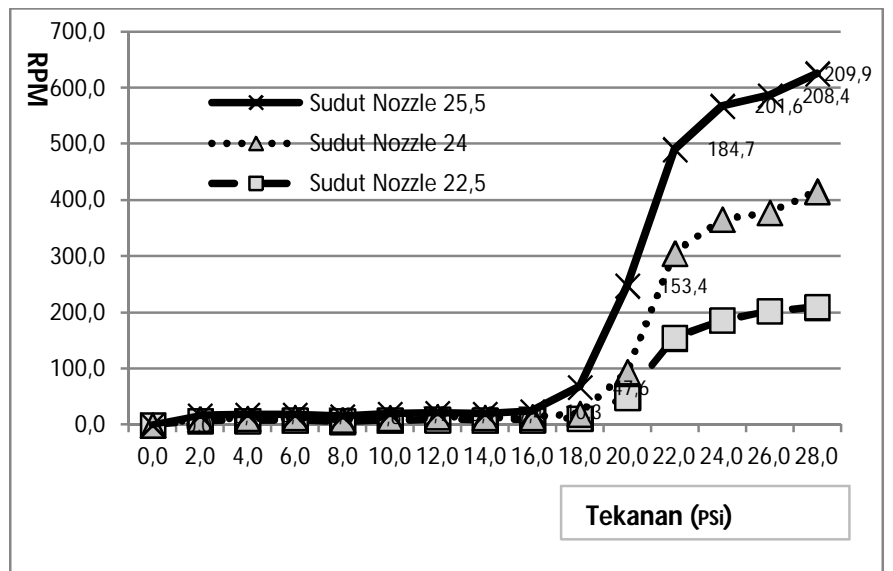

Gambar 6. Perbandingan sudut nozzle terhadap Tekanan

TABEL I

KONDISI POMPA TERHADAP SUDUT POSISI YANG MENGHASILKAN RPM TERTINGGI

\begin{tabular}{|c|c|c|c|c|c|}
\hline $\begin{array}{c}\text { Pompa } \\
\text { A }\end{array}$ & $\begin{array}{c}\text { Pompa } \\
\text { B }\end{array}$ & Tekanan & $\begin{array}{c}\text { Sudut } \\
\text { Nozzle }\end{array}$ & $\begin{array}{c}\text { Sudut } \\
\text { Posisi }\end{array}$ & RPM \\
\hline ON & OFF & 22 & 22,5 & 5 & 130,0 \\
\hline OFF & ON & 22 & 25,5 & 0 & 191,8 \\
\hline ON & ON & 28 & 22,5 & 0 & 231,0 \\
\hline
\end{tabular}

Sudut nozzle yang menghasilkan RPM tertinggi adalah pada sudut 22,5-25,5 dengan sudut posisi $0^{\circ}-5^{\circ}$, Tekanan yang dihasilkan pada saluran nozzle bukan merupakan penjumlahan dari tekanan masing-masing, hanya terjadi peningkatan sebesar 27\%. Dan RPM mengalami peningkatan sebesar $20 \%$.

\section{Kesimpulan}

RPM pada roda turbin Nest-Lie tidak menghasilkan perbedaan yang signifikan, dengan tekanan pada 28 Psi menghasilkan RPM berkisar antara 114,4 -130.8 dimana sudut posisi untuk $0 \mathrm{o} .5 \mathrm{o}, 10 \mathrm{o}, 15 \mathrm{o}$. RPM tertinggi untuk sudut posisi 5o dengan pada sudut nozzle 24o. Sedangkan RPM pada roda turbin Nest-Lie menghasilkan perbedaan yang sangat signifikan, dengan tekanan pada 28 Psi yang terbaca pada menghasilkan RPM berkisar antara 157,2 -231,1 dimana sudut posisi untuk 0o. 5o, 10o, 15o. RPM tertinggi untuk sudut posisi 0o dan dengan pada sudut nozzle 22,5o. dan Sudut nozzle yang menghasilkan RPM tertinggi adalah pada sudut 22,5-25,5 dengan sudut posisi 0o-5o. Tekanan yang dihasilkan pada saluran nozzle bukan merupakan penjumlahan dari tekanan masing-masing, hanya terjadi peningkatan sebesar 27\%. Dan RPM mengalami peningkatan sebesar $20 \%$.

\section{UCAPAN TERIMA KASIH}

Penulis menyampaikan ucapan terimakasih kepada LPPM Universitas Udayana yang telah memberikan dana penelitian ini skim hibah Penelitian Unggulan Udayana melalui DIPA PNBP Universitas Udayana TA-2018 sesuai dengan Surat Perjanjian Penugasan Pelaksanaan Penelitian Nomor : 38397/UN14.4/LT/2018, tanggal 28 Maret 2018

\section{REFERENSI}

[1] D. Agar and M. Rasi, "On the use of a laboratory-scale Pelton wheel water turbine in renewable energy education," Renew. Energy, vol. 33, no. 7, pp. 1517-1522, Jul. 2008.

[2] K. Smail and B. Andrew, "Best Practices for Sustainable Development of Micro hydro Power in Development Countries," The Department for International Development, UK and The World Bank, UK, Final Report, Mar. 2000.

[3] A. Prayitno, A. Awaluddin, and A. Anhar, "Renewable energy mapping at Riau Province: Promoting Energy Diversification for sustainable development (a case study)," presented at the 2010 Proceedings of the International Conference on Energy and Sustainable Development: Issues and Strategies (ESD), 2010, pp. $1-4$.

[4] G. P. Harrison and H. W. Whittington, "Investment in renewable energy: accounting for climate change," in 2002 IEEE Power Engineering Society Summer Meeting, 2002, vol. 1, pp. 140-144 vol.1.

[5] I. Ushiyama, "Renewable energy strategy in Japan," Renew. Energy, vol. 16, no. 1-4, pp. 1174-1179, Jan. 1999.

[6] Z. Naibo, S. Shingyi, and H. Zhengli, "Small-scale hydropower in China," Biomass, vol. 20, no. 1-2, pp. 77-102, 1989.

[7] S. P. Adhau, "A comparative study of micro hydro power schemes promoting self sustained rural areas," in International Conference on Sustainable Power Generation and Supply, 2009. SUPERGEN '09, 2009, pp. $1-6$.

[8] T. H. Ching, T. Ibrahim, F. I. A. Aziz, and N. M. Nor, "Renewable energy from UTP water supply," in 2011 International Conference on Electrical, Control and Computer Engineering (INECCE), 2011, pp. $142-147$.

[9] M. Pigaht and R. J. van der Plas, "Innovative private micro-hydro power development in Rwanda," Energy Policy, vol. 37, no. 11, pp. 4753-4760, Nov. 2009.

[10] O. Paish, "Small hydro power: technology and current status," Renew. Sustain. Energy Rev., vol. 6, no. 6, pp. 537-556, Dec. 2002.

[11] M. Djiteng, Pembangkitan Energi Listrik. Jakarta: Erlangga, 2005.

[12] L. Jasa, A. Priyadi, and M. H. Purnomo, "Designing angle bowl of turbine for Micro-hydro at tropical area," in 2012 International Conference on Condition Monitoring and Diagnosis (CMD), Sept., pp. 882-885.

[13] L. Jasa, P. Ardana, and I. N. Setiawan, "Usaha Mengatasi Krisis Energi Dengan Memanfaatkan Aliran Pangkung Sebagai Sumber Pembangkit Listrik Alternatif Bagi Masyarakat Dusun Gambuk -Pupuan-Tabanan,” in Proceding Seminar Nasional Teknologi Industri XV, ITS, Surabaya, 2011, pp. B0377-B0384.

[14] U. Navon, I. Zur, and D. Weiner, "Simulation model for optimising energy allocation to hydro-electric and thermal plants in a mixed thermal/hydro-electric power system," Gener. Transm. Distrib. Iee Proc. C, vol. 135, no. 3, pp. $182-188$, May 1988.

[15] S. Soares and C. T. Salmazo, "Minimum loss predispatch model for hydroelectric power systems," Ieee Trans. Power Syst., vol. 12, no. 3, pp. $1220-1228$, Aug. 1997.

[16] M. Mohibullah, A. M. Radzi, and M. I. A. Hakim, "Basic design aspects of micro hydro power plant and its potential development in Malaysia," in Power and Energy Conference, 2004. PECon 2004. Proceedings. National, 2004, pp. $220-223$.

[17] R. E. Doan and K. Natarajan, "Modeling and control design for governing hydroelectric turbines with leaky Wicket gates," Ieee Trans. Energy Convers., vol. 19, no. 2, pp. 449 - 455, Jun. 2004. 
[18] E. De Jaeger, N. Janssens, B. Malfliet, and F. Van De Meulebroeke, "Hydro turbine model for system dynamic studies," Ieee Trans. Power Syst., vol. 9, no. 4, pp. $1709-1715$, Nov. 1994.

[19] T. Sakurai, H. Funato, and S. Ogasawara, "Fundamental characteristics of test facility for micro hydroelectric power generation system," presented at the International Conference on Electrical Machines and Systems, 2009. ICEMS 2009, 2009, pp. 1 -6.

[20] I. F. G. Garcia, S. R. Lozano, and O. P. H. De La O, "Development of a Real Time Simulator to Test Load and Speed Control Systems of Hydroelectric Power Plants," in International Conference on Electrical, Communications, and Computers, 2009. CONIELECOMP 2009, 2009, pp. $250-255$.
[21] A. Wijesinghe and L. L. Lai, "Small hydro power plant analysis and development," in 2011 4th International Conference on Electric Utility Deregulation and Restructuring and Power Technologies (DRPT), 2011, pp. $25-30-$.

[22] L. M. O. de Mesquita, J. dos Santos Menas, E. L. van Emmenk, and M. Aredes, "Maximum power point tracking applied on small hydroelectric power plants," in 2011 International Conference on Electrical Machines and Systems (ICEMS), 2011, pp. 1 -6.

[23] L. Jasa, Ika Putri, A. Priyadi, and M. H. Purnomo, "Design optimization of micro hydro turbine using artificial particle swarm optimization and artificial neural network," Kursor, vol. 7, no. 3, pp. 135-144, oktober 2014. 